\title{
Tephra dispersal during the Campanian Ignimbrite (Italy) eruption: Implications for ultra-distal ash transport during the large caldera-forming eruption
}

Victoria C. Smith ${ }^{1 *}$, Roberto Isaia ${ }^{2}$, Sam L. Engwell ${ }^{3}$, Paul. G. Albert ${ }^{1}$

1. Research Laboratory for Archaeology and the History of Art, University of Oxford, Dyson Perrins Building, South Parks Road, Oxford OX1 3QY, UK

2. Istituto Nazionale di Geofisica e Vulcanologia, Osservatorio Vesuviano, via Diocleziano 328, 80154 Napoli, Italy

3. Istituto Nazionale di Geofisica e Vulcanologia, Sezione di Pisa, Via della Faggiola 32, 56126 Pisa, Italy

* corresponding author: victoria.smith@rlaha.ox.ac.uk

\begin{abstract}
The Campanian Ignimbrite eruption dispersed ash over much of the central eastern Mediterranean Sea and eastern Europe. The eruption started with a Plinian phase that was followed by a series of pyroclastic density currents (PDCs) associated with the collapse of the Plinian column and the caldera. The glass compositions of the deposits span a wide geochemical range but the Plinian fallout and PDCs associated with column collapse, the Lower Pumice Flow, only erupted the most evolved compositions. The later PDCs, the Breccia Museo and Upper Pumice Flow, erupted during and after caldera collapse, tap a less evolved component, and intermediate compositions that represent mixing between the end-members. The range of glass compositions in the Campanian Ignimbrite deposits from sites across the central and eastern Mediterranean Sea allow us to trace the dispersal of the different phases of this caldera-forming eruption. We map the
\end{abstract}


fallout from the Plinian column and the plumes of fine material associated with the PDCs (coPDCs) across the entire dispersal area. This cannot be done using the usual grain-size methods as deposits in these distal regions do not retain characteristics that allow attribution to either the Plinian or co-PDC phases. The glass compositions of the tephra at ultra-distal sites $(>1500 \mathrm{~km}$ from the vent) match those of the uppermost PDC units, suggesting that most of the ultra-distal dispersal was associated with the late co-PDC plume that was generated during caldera collapse.

Keywords: Campanian Ignimbrite; caldera-forming eruption; ash dispersal; co-PDC; Plinian; tephra 


\section{Introduction}

Large volumes of ash are dispersed over enormous areas of the globe during caldera-forming eruptions (e.g., the Youngest Toba Tuff, Matthews et al. 2012; Costa et al. 2014; the Changbaishan Millennium eruption, Sun et al. 2014). It is unknown what processes created the eruption column and ash cloud that carried the ash great distances $(1000 \mathrm{~s} \mathrm{~km})$ from the volcano. Establishing the amount of tephra that is dispersed from the Plinian eruption column and the plumes associated with pyroclastic density currents (PDCs), co-PDCs, is important for understanding the near-vent eruption dynamics, estimating the volume of material erupted, and the hazards posed by such eruptions. Such constraints are also invaluable for dispersal modelling, particularly for the estimation of eruption source parameters, which are significantly different for Plinian and co-PDC plumes, and to further understand the eruption processes during the evacuation of such large volumes of magma. Modelling the dispersal also allows the volumes of material erupted to be estimated and allows the potential impact of these eruptions to be more accurately assessed.

The Campanian Ignimbrite (CI) eruption occurred at 239 ka (De Vivo et al. 2001; Wood et al. 2012), generating the large caldera at Campi Flegrei, Italy. The event was the largest eruption in Europe since $100 \mathrm{ka}$ (Barberi et al. 1978). It dispersed 200-300 km³ of ash (Pyle et al., 2006; Costa et al. 2012; Marti et al. 2016) over a wide region to the east of the volcano (Fig. 1a) and to more than $2500 \mathrm{~km}$ from the vent. The tephra deposits blanket over 3.5 million $\mathrm{km}^{2}$ (Costa et al. 2012), forming visible tephra layers in numerous sedimentary records, including marine (the Y-5 marker layer; Keller et al. 1978), lacustrine, and archaeological sequences across southeastern Europe (e.g., Pyle et al. 2006; Giaccio et al. 2008). Although the CI is preserved as a visible tephra in many sections it is also found as a cryptotephra, a dilute layer of glass shards that are not visible to the naked eye, in many sedimentary records in distal areas (e.g., Lowe et al. 2012). The CI 
tephra has been confirmed at many of these sites across central and eastern Europe and the Mediterranean Sea based on the tephra thickness and its distinctive trachytic glass composition (e.g., Pyle et al. 2006). The tephra layer provides an invaluable absolute and relative chronological marker across the region, allowing the numerous archives to be correlated to investigate spatio-temporal variability in climate change and timing of human cultural events around central and eastern Europe (F.G. Fedele et al. 2003; 2008; Lowe et al. 2012).

CI eruption deposits

Proximal to medial fall deposits indicate the first phase of the eruption generated a Plinian column and dispersed pumice and ash directly eastward from the vent (Rosi et al. 1999; Fig. 1b). This Plinian fallout unit is $\sim 1.4$ m thick at the Voscone type section $\sim 40 \mathrm{~km}$ from the caldera, and thins to $\sim 15 \mathrm{~cm}$ at $120 \mathrm{~km}$ from the vent (Rosi et al. 1999). Two subunits are observed within the fall deposit; the lower subunit is well sorted and reversely graded while the upper subunit is crudely stratified, moderately sorted and richer in lithic clasts (Rosi et al. 1999). Rosi et al. (1999) estimated the total volume of the Plinian fallout unit to be $\sim 15 \mathrm{~km}^{3}$ and the maximum column height to be $\sim 44 \mathrm{~km}$.

Outcrops of PDC deposits associated with the CI eruption are commonly found on land up to 70 $\mathrm{km}$ from the vent (Barberi et al. 1978; Fig. 1b). These PDC deposits include dilute and highly concentrated currents. Various different PDC units have been identified in the CI deposits by Fisher et al. (1993), Rosi et al. (1996), Cappelletti et al. (2003), L. Fedele et al. (2008) and Scarpati and Perrotta (2012). Five main PDC units are observed on top of the Plinian fallout (Fig. 2) (Cappelletti et al. 2003; Scarpati and Perrotta 2012). In medial to distal locations, e.g., Lago Grande di Monticchio (LGdM) (Fig. 1b), the Plinian fallout unit is overlain by fine ash that is interpreted to be co-PDC deposits from these 5 PDCs (see below). 
The first PDC unit is an unconsolidated, stratified ash-flow (SAF) deposit, which was first described in detail by Cappelletti et al. (2003). This unit grades from a white colour at the base to slightly red at the top, and is less than $0.5 \mathrm{~m}$ thick close to the vent.

The second unit is a welded grey ignimbrite (WGI) that has also been described by Cappelletti et al. (2003). This WGI unit is subdivided into 2 subunits; the first is a monolithologic grey welded ignimbrite that has characteristic fiamme (flattened scoria) and grey lava fragments, and is often referred to as the Piperno facies (Rosi et al. 1996 and references therein; L. Fedele et al. 2008). This Piperno subunit can reach up to $20 \mathrm{~m}$ in thickness in proximal locations (Scarpati and Perrotta 2012). The second WGI subunit is a reversely graded, welded ignimbrite with black scoria in an ashy matrix, which reaches up to $45 \mathrm{~m}$ in thickness (Scarpati and Perrotta 2012). Scarpati and Perrotta (2012) suggest that this WGI unit is the main PDC unit preserved at medial sites in the Apennine Mountains (Fig. 1b).

The third PDC unit, Lower Pumice Flow Unit (LPF), is the thickest unit in proximal sections, reaching up to $\sim 60 \mathrm{~m}$ in thickness (Cappelletti et al. 2003; L. Fedele et al. 2008; Scarpati and Perrotta 2012). It is a mostly lithified and zeolitized yellow PDC unit with blocks of pumice and some denser, darker clasts. The upper parts are typically stratified and weakly welded (L. Fedele et al. 2008).

The fourth PDC unit is a distinct lithic-rich breccia, which is referred to the Breccia Museo (BM). The unit displays some crude stratification, has some juvenile pumice and obsidian clasts, and up to three distinct spatter agglutinate units within it (L. Fedele et al. 2008). The large volume of lithic fragments and their variety, along with the opening of new vents depositing the spatter, 
indicates that this BM deposit was associated with the major caldera-forming phase of the eruption (Rosi et al. 1996).

The uppermost PDC unit (UPF) is a poorly sorted PDC deposit with pumice and lithic clasts and has abundant degassing pipes (L. Fedele et al. 2008). This unit is up to $6 \mathrm{~m}$ thick close to the caldera (Scarpati and Perrotta 2012) and up to $2 \mathrm{~m}$ thick at locations $\sim 40 \mathrm{~km}$ from the vent (Cappelletti et al. 2003).

Composition of the proximal CI deposits

The proximal CI deposits have been chemically characterised in numerous publications (e.g., Rosi et al. 1996; Civetta et al. 1997; Pappalardo et al. 2002; 2007). These publications have typically used bulk rock data (major- and trace-element and isotopic compositions) to understand the magma evolution. These indicate that the magma was trachytic to phonolitic in composition, and tapped different magma bodies. Only limited glass chemistry has been published for the proximal CI deposits (Signorelli et al. 1999; Marianelli et al. 2006; L. Fedele et al. 2008; Tomlinson et al. 2012). Signorelli et al. (1999) published glass chemistry of the fall and co-PDC deposits, Marianelli et al. (2006) produced average compositional data for some samples from the fall and PDC deposits, Tomlinson et al. (2012) characterised the major- and trace-element chemistry from a few samples from the CI sequence, and L. Fedele et al. (2008) analysed glass compositions of juvenile components in the BM flow unit. Although there are data for the CI deposits, the glass composition has not been determined for a suite of samples that are fully representative of all phases of the eruptions.

Magnitude and dispersal of the CI eruption 
The CI tephra is found across the central and eastern Mediterranean Sea (Fig. 1a), and on land to the east of Italy. The dispersal area encompasses northern Libya in the south and River Don valley, Russia, in the northeast. The CI deposits have not been found on land west of the Campi Flegrei but they occur in a marine core $\sim 130 \mathrm{~km}$ south-southwest of the caldera (Paterne et al. 1988). The eruption plumes associated with the eruption clearly did not extend much to the west.

The thickness of the deposits around the Mediterranean Sea was incorporated into an ash dispersal model (FALL3D; Costa et al. 2006) by Costa et al. (2012) (single phase) and Marti et al. (2016) (two phases; Plinian and co-PDC plume) to estimate the best-fit column and eruption parameters and the volume of material erupted during the CI event. The results indicate that the Plinian eruption column was $\sim 44 \mathrm{~km}$ high and the total volume of fallout material associated with the Plinian phase was $54 \mathrm{~km}^{3}$, which equates to $\sim 23 \mathrm{~km}^{3}$ of magma (dense rock equivalent, DRE) (Marti et al. 2016). The results of Marti et al. (2016) suggest that both the Plinian and the co-PDC plume both dispersed tephra across most of the dispersal area but show that the co-PDC plume dispersed considerably more tephra; $\sim 154 \mathrm{~km}^{3}$ ( $\left.\sim 62 \mathrm{~km}^{3} \mathrm{DRE}\right)$. Once the volume of the PDC (Pyle et al. 2006) are considered, the total bulk volume for the CI eruption is estimated to be 430-680 $\mathrm{km}^{3}$, which is equivalent to $180-280 \mathrm{~km}^{3}$ DRE (Costa et al. 2012).

The dispersal of the Plinian and co-PDC phases

The dispersal of the Plinian and co-PDC phases of various eruptions have been mapped using grain-size (e.g., Rose et al. 2008), magnetic properties (Vigliotti 2015), and componentry (e.g. Eychenne et al. 2015) data. The latter has been used to map the dispersal of the Plinian and coPDC phases of the 1980 Mount St Helens eruption, USA, as the co-PDC deposits are microliterich (Eychenne et al. 2015). Unfortunately, such an approach would not work with the CI deposits as both the Plinian and co-PDC deposits are comprised of the same juvenile material, and there is 
no detectable change in shard morphology or mineralogy in the distal deposits. A recent study by Vigliotti (2015) shows that the magnetic properties of the CI deposits are variable, with the Plinian deposits having a noticeably different signal to that of the overlying PDC deposits. Vigliotti (2015) found that the magnetic properties of a distal sample in the Ionian Sea were consistent with it being deposited from the Plinian phase (Vigliotti 2015).

Engwell et al. (2014) used grain-size data from CI eruption deposits, sampled from sites across the Mediterranean Sea and eastern Europe, to investigate the dispersal of the Plinian and co-PDC phases. Sparks and Huang (1980) recognised that the distal deposits displayed a bimodal grainsize, with the different modes corresponding to the Plinian and co-PDC phases. The deposit in the LGdM (Fig. 1b) core has two distinct units separated by a sharp contact, the basal unit is $16 \pm 0.5$ cm thick and is composed of small pumice lapilli, lithic fragments and crystal grains while the upper unit is entirely fine-grained ash and is $18 \pm 5 \mathrm{~cm}$ thick. Engwell et al. (2014) found that the basal unit, which is inferred to represent the CI Plinian fallout, has a grain-size mode between 620 and $590 \mu \mathrm{m}$ (Fig. 3a). The deposit above is considerably finer, with a unimodal (25-30 $\mu \mathrm{m})$ grainsize, and is assumed to be associated with the co-PDC plume/s (Engwell et al. 2014; Fig. 3b). The two different grain-size modes continue to be observed up to $\sim 850 \mathrm{~km}$ from the vent but at greater distances, the deposits are unimodal and the Plinian versus co-PDC components can no longer be clearly separated (Engwell et al. 2014). Engwell et al. (2014) calculated that $40 \pm 5 \%$ of the volume of tephra within $850 \mathrm{~km}$ of the vent is associated with the Plinian phase of the eruption, and the rest $(60 \pm 6 \%)$ is fallout from the co-PDC plume. However, this ratio is likely to change across the dispersal area as the co-PDC plume was comprised of finer material that would have been transported further, and the Plinian and the co-PDC plumes may have had different dispersal axes and column heights. 
Here we attempt to use the glass composition of the CI tephra to map the dispersal of the Plinian and the co-PDC components over the entire dispersal region. We have characterised the glass chemistry of the fall and the PDC units at a range of proximal locations, where the stratigraphy is clear, to look at the compositional variation through the eruption sequence. These proximal glass compositions are then compared to those of distal deposits to map the dispersal of the different components of the CI eruption to establish what phase/s disperse the tephra into the ultra-distal (>1500 km from vent) regions. Grain-size information from sites within $900 \mathrm{~km}$ of Campi Flegrei is used to verify and further constrain the Plinian versus co-PDC components.

\section{Methods}

Grain-size analysis

The grain-size data refer to deposits in deep-sea and lake sediments. Where the Plinian and coPDC units could be identified, based on visual differences in the grain-size (e.g., at LGdM), samples were taken from each unit. At distal sites, the Plinian and co-PDC units could not be deciphered and samples were taken vertically through the deposit. The samples were taken at $1 \mathrm{~cm}$ intervals from units more than $1 \mathrm{~cm}$ thick. Grain-size information from Engwell et al. (2014) is used to define the contribution of the Plinian and co-PDC ash in locations within $900 \mathrm{~km}$ of Campi Flegrei, following the assumption that the coarse-grained mode represents the Plinian component, and the fine grained mode represents the co-PDC component. Although this assumption is somewhat simplistic it appears to hold for a number of deposits (e.g., Rose et al. 2008, Evans et al. 2009, Eychenne et al. 2012). The samples were treated with acetic acid and hydrogen peroxide to remove any biological and carbonate materials, respectively. The grain-size of deposits coarser than $500 \mu \mathrm{m}$ was determined by sieving at half-phi intervals. The grain-size of all finer material was determined by laser diffraction using the Malvern Mastersizer 2000 at the University of 
Rhode Island, USA. Sieve and laser data were combined following Eychenne et al. (2012). Grainsize data from Crvena Stijena Rockshelter, Montenegro, were digitised from Morley and Woodward (2011). Data for each sample were weighted according to thickness and merged to provide a representative grain-size distribution for each deposit. The bimodal distributions were separated into constituent distributions using the Kware Geological Software SFT application (sequential fragmentation/transport; Wohletz et al. 1989) assuming a log-normal distribution to provide information on the proportion of each constituent mode.

Sampling for glass geochemistry analysis

Proximal deposits of the CI were sampled from various locations around the Campi Flegrei caldera (Table 1; Fig. 1b and c). We also sampled some distal visible tephra layers observed in outcrops and marine cores (see Table 2). The details for the marine cores can be found in Keller et al. (1978), Watkins et al. (1978) and Sparks and Huang (1980). We attempted to obtain representative samples of all the proximal and distal units analysed in this study by sampling all juvenile components (clasts and ash) vertically through exposed sections. Coarser fractions of samples were lightly crushed and components from a range of clasts and ash were mounted in epoxy resin for analysis.

Electron microprobe analyses

Glass compositions were determined using a JEOL-8600 wavelength-dispersive electron microprobe at the Research Laboratory for Archaeology and the History of Art, University of Oxford. An accelerating voltage of $15 \mathrm{kV}$, beam current of $6 \mathrm{nA}$, and $10-\mu \mathrm{m}$-diameter beam were used for the analyses. Peak-count times were $30 \mathrm{~s}$ for $\mathrm{Si}, \mathrm{Al}, \mathrm{Fe}, \mathrm{Ca}, \mathrm{K}$ and $\mathrm{Ti} ; 50 \mathrm{~s}$ for $\mathrm{Cl}$ and $\mathrm{Mn}$; $60 \mathrm{~s}$ for $\mathrm{P}$; and $12 \mathrm{~s}$ for $\mathrm{Na}$. The electron microprobe was calibrated using a suite of mineral 
standards, and the PAP absorption correction method was used for quantification. The accuracy and precision of data were determined using repeat analyses on MPI-DING reference glasses (Jochum et al. 2006). All the glass analyses presented in this paper (including figures and tables), new and published, are presented as oxides and have been normalised to $100 \%$ for comparative purposes. The raw compositional data for proximal and distal glass shards and reference glasses analysed during all analytical runs are included in the Supplementary Material (SM1-SM3).

\section{Results}

Grain-size data

Grain-size data for various sites within $900 \mathrm{~km}$ of Campi Flegrei (Fig. 3) show that, at these locations, the deposits are composed of both a coarse- and fine-grained component, which have been related to the Plinian and co-PDC phases, respectively (Sparks and Huang 1980; Engwell et al. 2014). In the most proximal deposits, two distinct units are observed. The grain-size data of the basal, coarse deposit in the Lago Grande di Monticchio (LGdM) (Fig. 1b), related to the Plinian phase, have a mode of 1 phi (Fig. 3a). The grain-size of this Plinian deposit decreases towards the top of the deposit and becomes weakly bimodal (Fig. 4a). A considerably finer, unimodal (5.5 phi) deposit is found above a planar contact, and is assumed to be associated with the co-PDC plume/s (Engwell et al. 2014; Fig. 3b). The grain-size distributions of both deposits have long tails, with the Plinian fall deposit having a range of finer particles (Fig. 4a) and the co-PDC deposit having a range of coarser sizes (Fig. 4b).

The CI deposits outside Italy cannot be separated into different units based on visual analysis, but the deposits have bimodal grain-size distributions up to $\sim 900 \mathrm{~km}$ from the vent (Engwell et al. 2014; Fig. 3). The grain-size distributions of these deposits have been used to estimate the volume 
of Plinian to co-PDC fallout preserved at the sites (Table 2). The grain-size data from the deposit at Crevena Stijena Rockshelter, Montenegro, $420 \mathrm{~km}$ northeast of Campi Flegrei have a distinct coarse mode (data from Morley and Woodward 2011), which has been used to estimate that $\sim 63 \%$ of tephra was deposited from the Plinian phase. Deposits at sites southeast and east-southeast of Campi Flegrei are finer, and these data indicate that $35-52 \%$ of these deposits were from the Plinian column (Fig. 3c-f; Table 2). The coarse grain-size mode shows considerable variation between sites (Fig 4a), with a decrease in the grain-size with distance from vent, while the fine grain-size mode has very similar characteristics across the extent of the deposits (Fig 4b).

Glass composition of proximal CI deposits

All phases of the eruption were sampled from various outcrops around the caldera (Table 1; Fig. 1 and 2). The glass compositions of these CI proximal deposits span a wide range and classify as phonolite-trachyte with 58.97-62.27 wt.\% $\mathrm{SiO}_{2}$ and 12.49-14.29 wt.\% $\mathrm{Na}_{2} \mathrm{O}+\mathrm{K}_{2} \mathrm{O}(n=324)$ (Fig. 5). Two distinct end-member glass compositions are observed in the deposits. The Plinian phase and the LPF member of the PDC tapped the most evolved/differentiated compositions, with a range of 1.60-1.85 wt.\% $\mathrm{CaO}, 2.75-3.23$ wt.\% FeOt (all $\mathrm{Fe}$ as $\mathrm{FeO}$ ), 5.28-6.82 wt.\% $\mathrm{Na}_{2} \mathrm{O}, 7.02-$ 7.53 wt. $\% \mathrm{~K}_{2} \mathrm{O}$, and $0.88-1.15$ wt. $\% \mathrm{Cl}(n=152)$ (Table 3; Fig. 5). The glass compositions of samples of the WGI PDC unit, between the Plinian fallout and the LPF member, had variable $\mathrm{K}_{2} \mathrm{O}$ and $\mathrm{Na}_{2} \mathrm{O}$ compositions, which suggest that they had experienced alkali exchange (Scott 1971); thus, they do not reflect the original compositions and are not presented in this manuscript (data are included in the Supplementary Material). The least evolved/differentiated end member, with higher $\mathrm{MgO}$ (0.55-1.08 wt.\%), $\mathrm{CaO}$ (2.23-3.12 wt.\%), FeOt (3.23-4.18 wt.\%) and $\mathrm{K}_{2} \mathrm{O}$ (9.45-10.26 wt.\%), and lower $\mathrm{Na}_{2} \mathrm{O}(2.74-4.10$ wt.\%) and $\mathrm{Cl}(0.27-0.48$ wt.\%) appears in the BM PDC member $(n=93)$ but the evolved compositions continued to be tapped at the same time (Table 3; Fig. 5). The uppermost PDC unit, UPF, also has both components and additional intermediate 
compositions (Fig. 5). The full compositional range of the CI deposits is $0.78-3.12$ wt.\% CaO, 0.19-1.08 wt.\% MgO, 2.60-4.18 wt.\% FeOt, 2.74-6.99 wt.\% $\mathrm{Na}_{2} \mathrm{O}, 6.35-10.26$ wt.\% $\mathrm{K}_{2} \mathrm{O}$, and 0.27-1.21 wt.\% Cl ( $n=324)$ (Fig. 5).

\section{Discussion}

Compositional variation in the proximal CI deposits

The glass compositional data of this study clearly show that the first two phases of the eruption, the Plinian eruption column and the LPF PDCs associated with its collapse, erupted the most evolved compositions. Although no unaltered glass data were obtained for the PDC units below the LPF unit (SAF and WGI), the whole-rock data presented in other studies (Rosi et al. 1996; L. Fedele et al. 2008) indicate that they both also only erupted the most evolved compositions. The compositions tapped during these phases were also homogeneous, only erupting a limited range of compositions (Fig. 5). The emplacement of the lithic-rich breccia (BM) with spatter is indicative of caldera formation (Rosi et al. 1996) and this phase of the eruption also saw the introduction of the least evolved end-member. The later eruption of the least evolved magma is consistent with previous geochemical studies of the deposits (e.g., Civetta et al. 1997; Arienzo et al. 2011). The UPF member also tapped a wide range, with both the evolved and less evolved components, but also had intermediate compositions (Fig. 5). These different compositions were also noted in Civetta et al. (1997). It is clear that the least evolved compositions only began to be erupted during caldera formation. This is consistent with other studies of the CI deposits, e.g., the less evolved component is not observed in whole-rock analyses of the lower fallout and PDC samples of Rosi et al. (1996), Civetta et al. (1997), Pappalardo et al. (2002), L. Fedele et al. (2008) or Arienzo et al. (2011); furthermore, it is not seen in glass analyses of Marianelli et al. (2006) or Tomlinson et al. (2012). However, Signorelli et al. (1999) found some less evolved glasses in the Voscone Plinian 
fall unit (Vos $1 ; n=9$ of 28). The presence of these is inconsistent with our glass data from the Plinian fall at Voscone (Table 1), and those studies listed above. Furthermore, the Plinian fallout unit is well preserved in the core from LGdM (Wulf et al. 2004; Engwell et al. 2014), 130 km from the vent, where it has been chemically characterised (Wulf et al. 2004; Tomlinson et al. 2012) and the less evolved high- $\mathrm{K}_{2} \mathrm{O}$ component is not observed in their glass analyses. Thus, if the least evolved composition was indeed also erupted in the initial Plinian phase, as suggested by Signorelli et al. (1999), it clearly only makes up a minor component of the deposits.

Mapping Plinian versus co-PDC dispersal

Many glass compositional analyses have been published for distal CI tephra deposits $(n>800)$. Much of these distal data (Table 2) were either generated or collated from the literature for the RESET project (Lowe et al. 2015) and have been incorporated into the RESET database (Bronk Ramsey et al. 2015). We have used the published individual glass shard data from sites where there were more than 20 analyses and have acquired new data $(n=378)$ from other distal sites in areas for which there were no detailed, published glass chemistry data (see Table 2).

Given that the Plinian component of the CI eruption only erupted the most evolved magma, we can use the compositional range of the glass at the distal sites to infer whether these distal tephra deposits are associated with the Plinian phase or the later co-PDC phases of the CI eruption. The clearest way to quantify the components is to use the $\mathrm{K}_{2} \mathrm{O}$ compositions, as the Plinian fallout spans a narrow range in $\mathrm{K}_{2} \mathrm{O}(7.02-7.53$ wt.\%) and the upper PDCs (BM and UPF members associated with caldera collapse) have a wider range of $\mathrm{K}_{2} \mathrm{O}$ glass compositions that extends to higher values (Fig. 5). These late PDCs, generated during caldera collapse, are restricted to areas within $100 \mathrm{~km}$ of the vent, so the presence of the less evolved compositions at sites elsewhere implies that the dispersal was associated with the co-PDC plume from the PDCs. 
A prerequisite for this approach that uses compositional variations in the glass phase to map dispersal of the co-PDC and Plinian phases of the eruption is that the datasets from each of the sites is representative. The entire primary deposits must be chemically characterised to avoid sampling biases. Our new data (Table 2) are from samples taken vertically through the exposed units and therefore glass compositions are representative of the entire deposit. It is often not clear in the published literature how the deposits were sampled. At sites where the tephra layer is more than a few decimetres thick (e.g., at sites in Romania and in LGdM) the coarsest basal parts of the unit are likely to have been preferentially sampled and chemically characterised, as these lower parts are less likely to have been considered reworked, and also contain coarser material that is easier to analyse. It is unknown to what extent compositional biases may exist within these published glass datasets of the distal deposits, but they may be artificially dominated by the compositions that were erupted in the first phase of the eruption - the Plinian fallout (i.e. the most evolved component). Consequently, thinner layers could be more representative as the datasets are more likely to have been generated for samples of the entire deposit. Chemical biases could have also been introduced in the published datasets during data filtering, during which compositional outliers may be discarded, making the datasets seem more homogenous. However, we doubt that numerous outliers or entire subsidiary populations would have been removed from the published glass datasets.

The percentage of glass analyses in the proximal BM and UPF members that plot with the high$\mathrm{K}_{2} \mathrm{O}$ compositions, which are not observed in the Plinian fallout, is $62 \%$ and $51 \%$, respectively (Table 1). Thus, the proportion of the less evolved, high- $\mathrm{K}_{2} \mathrm{O}$ glasses at distal sites can be used to establish the amount of deposition related to late BM and UPF co-PDC fallout (Table 2). This is the minimum amount of co-PDC as the glass chemistry does not allow the LPF co-PDC to be distinguished from those of the Plinian deposits. Tephra at the ultra-distal sites northeast and 
southeast of Campi Flegrei (e.g., Kostenki, southeast Black Sea, and eastern Mediterranean Sea marine cores, Fig. 6) have a high proportion ( $>48 \%$ ) of the high- $\mathrm{K}_{2} \mathrm{O}$ compositions, which indicates that $>94 \%$ of the fallout at these sites was associated with the late co-PDC plume generated during caldera collapse (Table 2). The average glass data presented in Paterne et al. (1988) suggest that the most westerly occurrences of the CI, in the Tyrrhenian Sea, are dominated by high- $\mathrm{K}_{2} \mathrm{O}$ glass compositions, also consistent with association with the upper co-PDC plume and indicating it extended somewhat to the southwest.

All the new and published glass chemistry indicates that the tephra dispersals to the southeast and northeast within $1000 \mathrm{~km}$ of Campi Flegrei have predominantly evolved glasses, with $<20 \%$ high$\mathrm{K}_{2} \mathrm{O}$ glasses (Table 2; Fig. 6), and are clearly associated with the Plinian eruption column and/or the early co-PDC (LPF) phase. These sites southeast of Campi Flegrei include Haua Fteah, Libya (1130 km from vent; Douka et al. 2014; $\geq 27 \%$ Co-PDC) and marine cores in the Ionian Sea (V1069 with $\geq 39 \%$ and RC9-189 with $\geq 37 \%$ co-PDC; Fig. 6). The sites to the northeast within 1000 km of Campi Flegrei are in Montenegro (Crevena Stijena Rockshelter; Morley and Woodward 2011; $\geq 39 \%$ co-PDC), Macedonia (Golema Pesht cave; Lowe et al. 2012; $\geq 29 \%$ co-PDC) and Bulgaria (Kozarnika cave; Lowe et al. 2012; $\geq 14 \%$ co-PDC). Given the proximity to the vent, grain-size data can be used to further constrain whether dispersal along these axes is associated with a Plinian or LPF co-PDC plume (cf Engwell et al. 2014). All the sites within $900 \mathrm{~km}$ (Fig. 3 and Fig. 6; Table 2) have a wide range of grain-sizes, implying that deposition is associated with both the Plinian and the co-PDC phase. Grain-size data from Crevena Stijena Rockshelter in Montenegro (Morley and Woodward 2011; Fig. 3; Table 2), east-northeast of Campi Flegrei, indicate that the deposit is mostly associated with the Plinian fall ( $\sim 63 \%)$. The Plinian component makes up $13-52 \%$ of the deposits in the Ionian Sea, to the south-southeast of Campi Flegrei (Table 2). The rest of these deposits are associated with the LPF co-PDC plume and emplaced prior to caldera formation. These data clearly show that the dispersal axis for both the Plinian and LPF co- 
PDC plume moved during the eruption, from northeast to south-southeast. This difference in dispersal can be attributed by differences in plume height, with the inferred plume height of the co-PDC plume being considerably less than that of the Plinian plume (Marti et al. 2016).

The glass compositions indicate that the post-caldera-collapse co-PDC (BM and UPF) plume initially extended to the east-southeast of the vent. This plume did not extend much to the northeast within $1000 \mathrm{~km}$ of the vent, but since the low- $\mathrm{K}_{2} \mathrm{O}$ compositions dominate in areas more than $1000 \mathrm{~km}$ northeast of the vent (i.e. in the Kostenki, Russia; Fig. 6), the late co-PDC dispersal shifted towards the northeast at this distance from Campi Flegrei. These shifts in dispersal indicate that the wind direction and probably the weather conditions changed during the eruption.

Comparing the glass and grain-size results

The grain-size data can only inform on the Plinian versus co-PDC component within $900 \mathrm{~km}$ of the vent, where the distributions are bimodal. There are a few sites that we have both grain-size and glass chemistry data (Table 2). The glass data from the CI deposit at the Crevena Stijena Rockshelter in Montenegro (Morley and Woodward 2011), east-northeast of Campi Flegrei, indicates that at least $39 \%$ of the deposit is associated with the co-PDC plume. This is very consistent with the grain-size data from the deposit that suggests that $37 \%$ of the deposit was from the co-PDC plume (Fig. 3; Table 2). The glass chemistry of deposits in the Ionian Sea (V10-69 and RC9-189), southeast of Campi Flegrei, suggest that at least 37-39\% of each deposit is fallout from the co-PDC plume. However, the grain-size data suggest the co-PDC component in these deposits is considerably larger; 48\% in RC9-189 (640 km from vent) and 54\% in V10-69 (490 km from Campi Flegrei). This discrepancy between grain-size and glass data could suggest that some of the fine mode in the grain-size data, attributed to the co-PDC component, is actually from the Plinian column. It is common for the fine ash particles to aggregate (e.g., Brown et al., 2012) and 
thus, it is likely that some of the fine ash in these medial-distal locations fell as aggregates from the Plinian plume. The magnetic data also suggests that some of the finer ash in the Ionian Sea is from the Plinian phase (Vigliotti 2015). Alternatively, some of the fine ash is from the LPF coPDC plume that cannot be distinguished using the glass chemistry; as it has the same glass composition as the Plinian phase. Since the glass and grain-size methods estimate the same amount of co-PDC deposit north-northeast of the vent, it could support the assumption that the fine ash is associated with the co-PDC. Therefore, it could imply that the additional fine material in the Ionian Sea is associated with the LPF co-PDC plume and that this plume was dispersed to the southeast.

Applying this method to other eruptions

During explosive eruptions of large volumes of magma, the geometry of the conduit and mass eruption rate can change, altering eruption dynamics (e.g., Costa et al. 2009, Koyaguchi et al. 2009). The glass data indicates that another melt was erupted in the later stages of the CI eruption, and the deposits show that this coincided with a change in the eruption style. It is likely that the eruption of this new magma, with a different composition and physical properties, resulted in different conditions at the vent and led to the change in the eruption style. The formation of the PDCs, which generated co-PDC plumes, would have been driven by an increase in the mass eruption rate (e.g., Koyaguchi et al. 2009) associated with syn-eruptive changes of the vent geometry and different magma properties. The feedback between the processes during volcanic eruptions is complex and governs how the eruptions progress.

It appears that, during the climactic phases of large eruptions, a more diverse range of magma compositions are typically tapped, which are most likely associated with changes in vent geometry and mass eruption rate. For example, the glass chemistry of the Plinian fallout phase associated 
with the Oruanui super-eruption from Taupo Volcanic Zone, New Zealand (Wilson et al. 2005), is compositionally homogenous relative to the subsequent PDC deposits. This is even the case for significantly smaller eruptions such as the 1912 Novarupta eruption, Alaska (Hildreth 1983) and the Sant'Angelo eruption from Ischia, Italy (Tomlinson et al. 2014). Thus, this method of using the composition of the deposits to trace the dispersal associated with the Plinian eruption column versus co-PDC plume could be used for other eruptions. However, this method to estimate Plinian versus co-PDC dispersal requires that there are compositional differences between the Plinian and PDC units and that the samples collected from both proximal and distal sites are representative of the entire tephra sequence.

The chemistry of the deposits needs to be characterised vertically through the entire sequence from sites across the entire dispersal area. Unfortunately, such representative data do not exist for many eruptions, as many volcanological and petrological studies focus on a few samples from the major eruption units and are only sampled from a limited number of proximal locations. Furthermore, samples of distal units, especially those that do not have any physical stratigraphic variation, are typically only taken from the base of the unit to avoid any reworked material. The approach applied here would also only work for deposits of eruptions where there is sufficient outcrop in both proximal and distal locations, and could not be used for small eruptions or those from small volcanic islands where there is limited exposure of the tephra units. Nevertheless, this method could be used to further constrain the origin of ash deposits generated during many explosive eruptions and, in turn, evaluate the impact of these eruptions.

\section{Conclusions}

The glass compositional data clearly indicates that most of the ultra-distal dispersal during the CI eruption was associated with the late co-PDC plume that was generated during caldera collapse. Grain-size data also suggest that, even within $900 \mathrm{~km}$ of the vent, $\sim 60 \%$ of the deposition was 
associated with the co-PDC plume/s (Engwell et al. 2014). The dominance of the co-PDC component is linked to the fact that the PDCs produced the most voluminous deposits of the eruption. The ash in the co-PDC plumes is particularly fine so it can be easily lofted into the upper atmosphere and can be dispersed by both tropospheric and stratospheric winds over wide areas. These constraints on the dispersal associated with the Plinian and co-PDC phases of the CI eruption will enable more accurate models to be constructed to further understand the eruption dynamics during such large volcanic eruptions and to more accurately understand the impact of caldera-forming eruptions.

\section{Acknowledgements}

Enrico Iannuzzi, Madeleine Humphreys, Richard Brooker, Jenny Riker, Darren Mark, Tony Hinchliffe and Mike Stock helped with some of the proximal field sampling. PGA is funded by a Leverhulme Early Career Fellowship. We thank Antonio Costa for comments on a draft of the manuscript; Michael Ort and an anonymous reviewer for detailed reviews, and Costanza Bonadonna for constructive comments and editorial handling.

\section{References}

Arienzo I, Heumann A, Wörner G, Civetta L, Orsi G (2011). Processes and timescales of magma evolution prior to the Campanian Ignimbrite eruption (Campi Flegrei, Italy). Earth Planet Sc Lett 306:217-228. doi:10.1016/j.eps1.2011.04.002

Barberi F, Innocenti F, Lirer L, Munno R, Pescatore T, Santacroce R (1978) The Campanian Ignimbrite: a major prehistoric eruption in the Neapolitan area (Italy). B Volcanol 41:10-31. doi: 10.1007/BF02597680 
Bronk Ramsey C, Housley RA, Lane CS, Smith VC, Pollard AM (2015) The RESET tephra database and associated analytical tools. Quaternary Sci Rev 118:33-47. doi:10.1016/j.quascirev.2014.11.008

Brown RJ, Bonadonna C, Durant AJ (2012) A review of volcanic ash aggregation. Phys Chem Earth Pt A/B/C 65:1474-7065. doi:10.1016/j.pce.2011.11.001

Cappelletti P, Cerri G, Colella A, de'Gennaro M, Langella A, Perrotta A, Scarpati C (2003) Post-eruptive processes in the Campanian Ignimbrite. Miner Petrol 79:79-97. doi:10.1007/s00710-003-0003-7

Caron BT, Sulpizio R, Zanchetta G, Siani G, Santacroce R (2010) The Late Holocene to Pleistocene tephrostratigraphic record of Lake Ohrid (Albania). CR Geosci 342:453-466. doi:10.1016/j.crte.2010.03.007

Civetta L, Orsi G, Pappalardo L, Fisher RV, Heiken G, Ort M (1997) Geochemical zoning, mingling, eruptive dynamics and depositional processes - the Campanian Ignimbrite, Campi Flegrei caldera, Italy. J Volcanol Geoth Res 75:183-219. doi:10.1016/S0377-0273(96)00027-3 Costa A, Folch A, Macedonio G, Giaccio B, Isaia R, Smith VC (2012) Quantifying volcanic ash dispersal and impact of the Campanian Ignimbrite super-eruption. Geophys Res Lett 39:L10310. doi:10.1029/2012GL051605

Costa A, Macedonio G, Folch A (2006) A three-dimensional Eulerian model for transport and deposition of volcanic ashes. Earth Planet Sc Lett 241:634-647. doi:10.1016/j.eps1.2005.11.019.

Costa A, Smith VC, Macedonio G, Matthews NE (2014) The magnitude and impact of the Youngest Toba Tuff super-eruption. Front Earth Sci 2:1-8. doi:10.3389/feart.2014.00016 Costa A, Sparks RSJ, Macedonio G, Melnik O (2009) Effects of wall-rock elasticity on magma flow in dykes during explosive eruptions. Earth Planet Sc Lett 288:455-462, doi: 10.1016/j.epsl.2009.10.006 
Cullen VL, Smith VC, Arz HW (2014) The detailed tephrostratigraphy of a core from the south-east Black Sea spanning the last $\sim 60 \mathrm{ka}$. J Quaternary Sci 29:675-690. doi:10.1002/jqs.2739

Damaschke M, Sulpizio R, Zanchetta G, Wagner B, Böhm A, Nowaczyk N, Rethemeyer J, Hilgers A (2013) Tephrostratigraphic studies on a sediment core from Lake Prespa in the Balkans. Clim Past 9:267-287. doi:10.5194/cp-9-267-2013

De Vivo B, Rolandi G, Gans PB, Calvert A, Bohrson WA, Spera FJ, Belkin HE (2001) New constraints on the pyroclastic eruptive history of the Campanian volcanic Plain (Italy). Miner Petrol 73:47-65. doi: 10.1007/s007100170010

Douka K, Jacobs Z, Lane C, Grün R, Farr L, Hunt C, Inglis RH, Reynolds T, Albert P, Aubert M, Cullen V, Hill E, Kinsley L, Roberts RG, Tomlinson EL, Wulf S, Barker G (2014) The chronostratigraphy of the Haua Fteah cave (Cyrenaica, northeast Libya). J Hum Evol 66:39-63. doi:10.1016/j.jhevol.2013.10.001

Engwell SL, Sparks RSJ, Carey S (2014) Physical characteristics of tephra layers in the deep sea realm: the Campanian Ignimbrite eruption. In: Austin WEN, Abbott PM, Davies SM, Pearce NJG, Wastegard S (eds) Marine Tephrochronology, vol 398. Geological Society, London, Special Publications, p 47-64. doi:10.1144/SP398.7

Evans JR, Huntoon JE, Rose WI, Varley NR, Stevenson JA (2009) Particle sizes of andesitic ash fallout from vertical eruptions and co-pyroclastic flow clouds, Volcan de Colima, Mexico. Geology 37: 935-938. doi: 10.1130/G30208A.1

Eychenne J, Le Pennec JL, Troncoso L, Gouhier M, Nedelec JM (2012) Causes and consequences of bimodal grain-size distribution of tephra fall deposited during the August 2006 Tungurahua eruption (Ecuador). B Volcanol 74:187-205, doi:10.1007/s00445-011-0517-5

Eychenne J, Cashman K, Rust A, Durant A (2015). Impact of the lateral blast on the spatial pattern and grain size characteristics of the 18 May 1980 Mount St. Helens fallout deposit. J. Geophys. Res. Solid Earth 120: 6018-6038. doi:10.1002/(ISSN)2169-9356 
Fedele FG, Giaccio B, Isaia R, Orsi G (2003) The Campanian Ignimbrite Eruption, Heinrich Event 4, and palaeolithic change in Europe: A high-resolution investigation. In: Geophysical Monograph Series, American Geophysical Union, Washington, D. C., 139, pp. 301-325. doi:10.1029/139GM20

Fedele FG, Giaccio B, Hajdas I (2008) Timescales and cultural process at 40,000 BP in the light of the Campanian Ignimbrite eruption, Western Eurasia. J Hum Evol 55:834-857. doi:10.1016/j.jhevol.2008.08.012

Fedele L, Scarpati C, Lanphere M, Melluso L, Morra V, Perrotta A, Ricci G (2008) The Breccia Museo formation, Campi Flegrei, southern Italy: geochronology, chemostratigraphy and relationship with the Campanian Ignimbrite eruption. B Volcanol 70:1189-1219. doi:10.1007/s00445-008-0197-y

Fisher RV, Orsi G, Ort M, Heiken G (1993) Mobility of a large-volume pyroclastic flowemplacement of the Campanian ignimbrite, Italy. J Volcanol Geoth Res 56:205-220. doi:10.1016/0377-0273(93)90017-L

Giaccio B, Isaia R, Fedele FG, Di Canzio E, Hoffecker J, Ronchitelli A, Sinitsyn AA, Anikovich M, Lisitsyn SN, Popov VV (2008) The Campanian Ignimbrite and Codola tephra layers: Two temporal/stratigraphic markers for the Early Upper Palaeolithic in southern Italy and eastern Europe. J Volcanol Geoth Res 177: 208-226. doi:10.1016/j.jvolgeores.2007.10.007 Hildreth W (1983) The compositionally zoned eruption of 1912 in the Valley of Ten Thousand Smokes, Katmai National Park, Alaska. J Volcanol Geoth Res 18:1-56. doi:10.1016/03770273(83)90003-3

Ivanova S, Gurova M, Spassov N, Hristova L, Tzankov N, Popov V, Marinova E, Makedonska J, Smith V, Ottoni C, Lewis M (In press) Magura Cave, Bulgaria: a multidisciplinary study of Late Pleistocene human palaeoenvironment in the Balkans. Quatern Int. doi:10.1016/j.quaint.2015.11.082 
Jochum KP, Stoll B, Herwig K, Willbold M, Hofmann AW, Amini M, Aarburg S, Abouchami W, Hellebrand E, Mocek B, Raczek I, Stracke A, Alard O, Bouman C, Becker S, Dücking M, Brätz H, Klemd R, de Bruin D, Canil D, Cornell D, de Hoog C, Dalpé C, Danyushevsky L, Eisenhauer A, Gao Y, Snow JE, Groschopf N, Günther D, Latkoczy C, Guillong M, Hauri E, Höfer HE, Lahaye Y, Horz K, Jacob DE, Kasemann SA, Kent AJR, Ludwig T, Zack T, Mason PRD, Meixner A, Rosner M, Misawa K, Nash BP, Pfänder J, Premo WR, Sun WD, Tiepolo M, Vannucci R, Vennemann T, Wayne D, Woodhead JD (2006) MPI-DING reference glasses for in situ microanalysis: new reference values for element concentrations and isotope ratios. Geochem Geophy Geosy 7:Q02008. doi. 10.1029/2005GC001060.

Keller J, Ryan WBF, Ninkovich D, Altherr R (1978) Explosive volcanic activity in the Mediterranean over the past $200,000 \mathrm{yr}$ as recorded in deep-sea sediments. Geol Soc of Am Bull 89: 591-604. doi:10.1130/0016-7606(1978)89<591:EVAITM>2.0.CO;2

Koyaguchi T, Suzuki YJ, Kozono T (2010) Effects of the crater on eruption column dynamics. J Geophys Res 115:B07205. doi:10.1029/2009JB007146

Lowe JJ, Barton N, Blockley S, Ramsey CB, Cullen VL, Davies W, Gamble C, Grant K, Hardiman M, Housley R, Lane CS, Lee S, Lewis M, MacLeod A, Menzies MA, Muller W, Pollard M, Price C, Roberts AP, Rohling EJ, Satow C, Smith VC, Stringer CB, Tomlinson EL, White D (2012) Volcanic ash layers illuminate the resilience of Neanderthals and early modern humans to natural hazards. P Natl Acad Sci USA 109:13532-13537.

Lowe JJ, Ramsey CB, Housley RA, Lane CS, Tomlinson EL, RESET Team, RESET Associates (2015) The RESET project: constructing a European tephra lattice for refined synchronisation of environmental and archaeological events during the last c. $100 \mathrm{ka}$. Quaternary Sci Rev 118: 1-17. doi:10.1016/j.quascirev.2015.04.006

Margari V, Pyle DM, Bryant C, Gibbard PL (2007) Mediterranean tephra stratigraphy revisited: results from a long terrestrial sequence on Lesvos island, Greece. J Volcanol Geoth Res 163:3454. doi:10.1016/j.jvolgeores.2007.02.002 
Marianelli P, Sbrana A, Proto M (2006) Magma chamber of the Campi Flegrei supervolcano at the time of eruption of the Campanian Ignimbrite. Geology 34:937-940. doi:10.1130/G22807A.1

Marti A, Folch A, Costa A, Engwell S (2016) Reconstructing the plinian and co-ignimbrite sources of large volcanic eruptions: A novel approach for the Campanian Ignimbrite. Sci Rep 6:21220. doi:10.1038/srep21220

Matthews NE, Smith VC, Costa A, Durant AJ, Pyle DM, Pearce NJG (2012) Ultra-distal tephra deposits from super-eruptions: Examples from Toba, Indonesia and Taupo Volcanic Zone, New Zealand. Quatern Int 258:54-79. doi:10.1016/j.quaint.2011.07.010

Morley MW, Woodward JC (2011) The Campanian Ignimbrite (Y5) tephra at Crvena Stijena Rockshelter, Montenegro. Quaternary Res 75:683-696. doi:10.1016/j.yqres.2011.02.005

Pappalardo L, Civetta L, De Vita S, Di Vito M, Orsi G, Carandente A, Fisher RV (2002) Timing of magma extraction during the Campanian Ignimbrite eruption (Campi Flegrei Caldera). J Volcanol Geoth Res 114: 479-497. doi:10.1016/S03770273(01)00302-X

Pappalardo L, Ottolini L, Mastrolorenzo G (2007) The Campanian Ignimbrite (southern Italy) geochemical zoning: insight on the generation of a super-eruption from catastrophic differentiation and fast withdrawal. Contrib Mineral Petr 156:1-26. doi:10.1007/s00410-0070270-0

Paterne M, Guichard F, Labeyrie J (1988) Explosive activity of the South Italian volcanoes during the past 80,000 years as determined by marine tephrochronology. J Volcanol Geoth Res 34:153-172. doi:10.1016/0377-0273(88)90030-3

Perrotta A, Scarpati C (2003) Volume partition between the plinian and co-ignimbrite air fall deposits of the Campanian Ignimbrite eruption. Miner Petrol 79:67-78. http://doi.org/10.1007/s00710-003-0002-8

Pyle DM, Ricketts GD, Margari V, van Andel TH, Sinitsyn AA, Praslov ND, Lisitsyn S (2006) Wide dispersal and deposition of distal tephra during the Pleistocene "Campanian 
Ignimbrite/Y5" eruption, Italy. Quaternary Sci Rev 25:2713-2728. doi:10.1016/j.quascirev.2006.06.008

Rolandi G, Bellucci F, Heizler MT, Belkin HE, De Vivo B (2003) Tectonic controls on the genesis of ignimbrites from the Campanian Volcanic Zone, southern Italy. Miner Petrol 79: 331. doi:10.1007/s00710-003-0014-4

Rose WI, Self S, Murrow PJ, Bonadonna C, Durant AJ, Ernst GGJ (2008). Nature and significance of small volume fall deposits at composite volcanoes: Insights from the October 14, 1974 Fuego eruption, Guatemala. B Volcanol 70:1043-1067. doi:10.1007/s00445-007$0187-5$

Rosi M, Vezzoli L, Aleotti P, De Censi M (1996) Interaction between caldera collapse and eruptive dynamics during the Campanian Ignimbrite eruption, Phlegraean Fields, Italy. B Volcanol 57:541-554. doi:10.1007/BF00304438

Rosi M, Vezzoli L, Castelmenzano A, Grieco G (1999) Plinian pumice fall deposit of the Campanian Ignimbrite eruption (Phlegraean Fields, Italy). J Volcanol Geoth Res 91:179-198. doi:10.1016/S0377-0273(99)00035-9

Scarpati C, Perrotta A (2012) Erosional characteristics and behavior of large pyroclastic density currents. Geology 40:1035-1038. doi:10.1130/G33380.1

Scott RB (1971) Alkali exchange during devitrification and hydration of glasses in ignimbrite cooling units. J Geol 79: 100-110.

Signorelli S, Vaggelli G, Francalanci L, Rosi M (1999) Origin of magmas feeding the Plinian phase of the Campanian Ignimbrite eruption, Phlegrean Fields (Italy): constraints based on matrix-glass and glass-inclusion compositions. J Volcanol Geoth Res 91:199-220. doi:10.1016/S0377-0273(99)00036-0

Sparks RSJ, Huang TC (1980) The volcanological significance of deep sea tephra layers associated with ignimbrites. Geol Mag 117:425-436. doi:10.1017/S0016756800028533 
Sun C, Plunkett G, Liu J, Zhao H, Sigl M (2014) Ash from Changbaishan Millennium eruption recorded in Greenland ice: Implications for determining the eruption's timing and impact. Geophys Res Lett 41. doi:10.1002/2013GL058642.

Tomlinson EL, Arienzo I, Wulf S, Smith, VC, Carandente A, Civetta L, Hardiman M, Lane CS, Orsi G, Rosi M, Thirlwall MT, Muller W, Menzies MA (2012) Geochemistry of the Phlegraean Fields (Italy) proximal sources for major Mediterranean tephras: Implications for the dispersal of Plinian and co-ignimbritic components of explosive eruptions. Geochim Cosmochim Ac 93:102-128. doi:10.1016/j.gca.2012.05.043

Tomlinson EL, Albert PG, Wulf S, Brown RJ, Smith VC, Keller J, Orsi G, Bourne AJ, Menzies MA (2014) Age and geochemistry of tephra layers from Ischia, Italy: constraints from proximal-distal correlations with Lago Grande di Monticchio. J Volcanol Geoth Res 287:2239. doi:10.1016/j.jvolgeores.2014.09.006

Veres D, Lane CS, Timar-Gabor A, Hambach U, Constantin D, Szakács A, Füllinge A, Onac BP (2013) The Campanian Ignimbrite/Y5 tephra layer - A regional stratigraphic marker for Isotope Stage 3 deposits in the Lower Danube region, Romania. Quatern Int 293:22-33. doi:10.1016/j.quaint.2012.02.042

Vigliotti L (2015) Magnetic properties of the Campanian Ignimbrite and the marine Y5 tephra layer. In: Ort MH, Porreca M, Geissman JW (eds) The Use of Palaeomagnetism and Rock Magnetism to Understand Volcanic Processes, vol 396. Geological Society, London, Special Publications, p. 227-238. doi:10.1144/SP396.1

Vitale S, Isaia, R (2014) Fractures and faults in volcanic rocks (Campi Flegrei, southern Italy): insight into volcano-tectonic processes. Int J Earth Sci 103:801-819. doi:10.1007/s00531-0130979-0

Vogel H, Zanchetta G, Sulpizio R, Wagner B, Nowaczyk N (2010) A tephrostratigraphic record for the last glacial-interglacial cycle from Lake Ohrid, Albania and Macedonia. J Quaternary Sci 25:320-338. doi: 0.1002/jqs.1311 
Wagner B, Sulpizio R, Zanchetta G, Wulf S, Wessels M, Daut G, Nowaczyk N (2008) The last 40 ka tephrostratigraphic record of Lake Ohrid, Albania and Macedonia: a very distal archive for ash dispersal from Italian volcanoes. J Volcanol Geoth Res 177:71-80. doi:10.1016/j.jvolgeores.2007.08.018

Watkins ND, Sparks R, Sigurdsson H, Huang TC, Federman A, Carey S, Ninkovich D (1978) Volume and extent of the Minoan tephra from Santorini Volcano: new evidence from deep-sea sediment cores. Nature 271:122-126. doi:10.1038/271122a0

Wilson CJN, Blake S, Charlier BLA, Sutton AN (2005) The 26.5 ka Oruanui Eruption, Taupo Volcano, New Zealand: Development, Characteristics and Evacuation of a Large Rhyolitic Magma Body. J Petrol 47:35-69. doi:10.1093/petrology/egi066

Wohletz KH, Sheridan MF, Brown WK (1989) Particle size distributions and the sequential fragmentation/transport theory applied to volcanic tephra. J Volcanol Geoth Res 94:1570315721. doi:10.1029/JB094iB11p15703

Wood R, Douka K, Boscato P, Haesaerts P, Sinitsyn A, Higham TFG (2012) Testing the ABOx-SC method: dating known-age charcoals associated with the Campanian Ignimbrite. Quat Geochronol 9:16-26. doi:10.1016/j.quageo.2012.02.003

Wulf S, Kraml M, Brauer A, Keller J, Negendank JFW (2004) Tephrochronology of the 100ka lacustrine sediment record of Lago Grande di Monticchio (southern Italy). Quatern Int 122:730. doi:10.1016/j.quaint.2004.01.028 


\section{Tables}

Table 1. Details and descriptions of proximal Campanian Ignimbrite samples collected in this study.

Footnote: $\mathrm{CF}=$ Campi Flegrei, Strat. $=$ stratigraphic. ${ }^{*}$ see Fig. 2. Locations are shown on Fig. 1.

Table 2. Details and descriptions of distal Campanian Ignimbrite tephra samples used and analysed in this study.

Footnote: ** Proximal PDC deposits, and their associated co-PDC deposits, have both low- and high $-\mathrm{K}_{2} \mathrm{O}(>51 \%)$ glass analyses, while the Plinian deposits only have shards with low- $\mathrm{K}_{2} \mathrm{O}$ glass compositions. The ratio was calculated assuming that if $51 \%$ of the glass analyses were high- $\mathrm{K}_{2} \mathrm{O}$ then the deposit was entirely associated with the co-PDC plume. ${ }^{*}$ These data are not thought to be representative as the compositional range is different from that of Castelcivita. Given the thickness of the tephra at Lago Grande di Monticchio, it is likely that only the coarse Plinian unit and the lower part of the fine unit (see Wulf et al. 2004) were sampled for analysis. Sites in close proximity have been combined, e.g., Lake Ohrid and Prespa in the Balkans, and sites in the Lower Danube valley, Romania.

Table 3. Representative glass compositions of the proximal Campanian Ignimbrite stratigraphic units.

Footnote: See Table 1 for site information. See the Supplementary Material for all the raw data.

\section{Figures}

Fig. 1. (a) Locations where distal Campanian Ignimbrite tephra is found (red boxes) and the general dispersal area (shaded). (b) Isopach map of the Plinian fall deposits (in $\mathrm{cm}$ ) and locations where the flow units are exposed, modified from Giaccio et al. (2008) (Table 1). Plinian thickness measurements are from Rosi et al. (1999), Rolandi et al. (2003) and Perrotta 
and Scarpati (2003). (c) Map of the Campi Flegrei caldera and its major structures, modified from Vitale and Isaia (2014). The locations where the Campanian Ignimbrite samples were taken (Table 1) are marked and labeled on (a) and (b). The medial Castelcivita Cave site and Lago Grande di Monticchio (Table 2) sites are also labeled. The Neopolitan Yellow Tuff (NYT) eruption occurred at $\sim 15 \mathrm{ka}$.

Fig. 2. The main stratigraphic units observed in the Campanian Ignimbrite deposits. These units have been defined based on descriptions of Rosi et al. (1996), Rosi et al. (1999), Cappelletti et al. (2003), L. Fedele et al. (2008) and Scarpati and Perrotta (2012). The units to which the proximal samples (CF labels) collected in this study correspond are shown (see Table 1 for more information). The stratigraphic column is modified from L. Fedele et al. (2008).

Fig. 3. Grain-size distributions of the Campanian Ignimbrite deposit at various distances from source (see Fig. $1 \mathrm{~b}$ and 5 for locations). Two distinct units are clearly observed in the deposit at Lago Grande di Montichhio (LGdM); the Plinian deposit at the base (A), overlain by a very fine-grained ash layer interpreted as the co-PDC ash (b). More distal deposits (C-F; grey bars) cannot be separated stratigraphically into Plinian and co-PDC ash but are bimodal, with the different modes representing different phases of the eruption and given as a ratio (Plinian:coPDC). Data from Crvena Stijena, Montenegro (c) has been digitised from Morley and Woodward (2011) and resampled.

Fig. 4. Deconvolved grain-size data for the (a) coarse, Plinian, and (b) fine, co-PDC modes. While the grain-size of the coarse Plinian mode varies significantly, the grain-size of the fine, co-PDC mode are remarkably similar over large distances.

Fig. 5. Glass composition of the Campanian Ignimbrite at proximal sites. Note strong compositional variation vertically through the sequence. See Fig. 2 for details of the stratigraphic units. Error bars are based on $95 \%$ confidence counting statistics and are larger than the reproducibility on secondary standards (see Supplementary Material, SM3). 
Fig. 6. Histograms of the $\mathrm{K}_{2} \mathrm{O}$ glass compositions of the Campanian Ignimbrite tephra at sites across Eastern Europe and the Mediterranean (see Kostenki or proximal histograms for the bin ranges). The black shaded part of the histograms shows the most evolved compositions, which dominate the early Plinian and LPF deposits. The sites with $>30 \%$ of the high- $\mathrm{K}_{2} \mathrm{O}$ compositions (marked with circles, also see Table 2) are predominantly associated with the late caldera-forming phases and deposited from the co-PDC plume. The other sites, marked with stars, mostly have low- $\mathrm{K}_{2} \mathrm{O}$ glass compositions and are deposits of the Plinian column and early LPF co-PDC phase. Sites marked with a cross have grain-size data (see Table 2 and Fig. 3) but there are no glass chemistry data for the tephra at these sites. The black transparent fields outlined in white show the dispersal of the early eruption phases, the Plinian and LPF co-PDC plume. The grain-size data (Fig. 3) indicates that the field labeled 1 is the predominant trajectory of the Plinian plume, while the deposits in the Ionian sea (field labeled 2) are associated with both the Plinian and the LPF co-PDC plume (generated from the collapse of the Plinian column). However, the Plinian plume deposited ash northeast and southeast of the vent, indicating that the plumes moved significantly. The light grey field outlined in black (labeled 3) links the sites with high proportions of the less evolved compositions, and shows the main trajectory of the late co-PDC plume that was generated during caldera collapse. References for the glass data are provided in Table 2. Proximal sample locations are marked on Fig. 1b and c.

\section{Supplementary Material}

SM1. Glass analyses of the proximal Campanian Ignimbrite samples analysed in this study (see Table 1 for sample details).

SM2. Glass analyses of distal Campanian Ignimbrite tephras analysed in this study (see Table 2 for sample details). 
SM3. Analyses of the MPI-DING reference glasses (Jochum et al. 2006) that were used as secondary standards for analytical runs on the electron microprobe. 